Available online:

http://journal.imla.or.id/index.php/arabi

Arabi : Journal of Arabic Studies, 5 (2), 2020, 191-200

DOI: http://dx.doi.org/10.24865/ajas.v5i2.257

\title{
SISTEM KAJI DUDUAK SEBAGAI STRATEGI PEMBELAJARAN MAHARAH AL-QIRA'AH DI MADRASAH BATANG KABUNG
}

\author{
Supriadi Ansyah, Mahyudin Ritonga, Fitri Alrasi \\ Universitas Muhammadiyah Sumatera Barat, Padang, Indonesia \\ E-mail : mahyudin.ritongga@umsb.ac.id
}

\begin{abstract}
This research aims to expose the system of Kaji Duduak as one of the strategies for learning qira'ah, specifically the aspects that will be exposed in this study are related to learning materials qira'ah, implementation methods and measures of use of the system Kaji Duduak as a strategy of learning qiräah. The method of research used is qualitative with a phenomenological approach, data collection is done by observation, interviews and documentation. Data analysis techniques used classification, display and draw conclusions, to the validity of data use triangulation. The results of the study were: 1) learning materials qirä'ah with a strategy kaji Duduak sourced from kitab kuning, 2) The implementation method more emphasis on qirā'ah jahriyah, 3) measures used in teaching the mahärah qirä'ah with the strategy of Kaji Duduak: a) Students seated in the presence of ustadz, b) Teachers read the book that is listened to by students, c) Students are asked to restart the readings in turns, d) Reading material is analyzed using certain codes and distinctive mentions with Minang language, e) reading material translated based on i'rāb.
\end{abstract}

Keywords: strategy, kaji duduak, Arabic learning, mahārah al-qirā’ah

\section{Abstrak}

Penelitian ini bertujuan untuk mengekspos sistem kaji duduak sebagai salah strategi pembelajaran qirä'ah, secara khusus aspek-aspek yang akan diekspos dalam penelitian ini ialah terkait materi pembelajaran qirä'ah, metode pelaksanaan serta langkahlangkah penggunaan sistem kaji duduak sebagai strategi pembelajaran qirä'ah. Metode penelitian yang digunakan ialah kualitatif dengan pendekatan fenomenologi, pengumpulan data dilakukan dengan observasi, wawancara dan dokumentasi. Teknik analisis data digunakan klasifikasi, display dan penarikan kesimpulan, untuk pencermatan keabsahan data digunakan triangulasi. Hasil penelitian ialah: 1) Materi pembelajaran qirăah dengan strategi kaji duduak bersumber dari kitab kuning, 2) Metode pelaksanaan lebih menekankan pada qirā'ah jahriyah, 3) langkah-langkah yang digunakan dalam mengajarkan mahārah al-qirā'ah dengan strategi kaji duduak: a) santri duduk berlingkar di hadapan ustadz, b) guru membaca kitab yang didengarkan oleh santri, c) santri diminta mengulang kembali bacaan secara bergiliran, d) materi bacaan dii'rāb dengan menggunakan kode-kode tertentu serta penyebutan yang khas dengan bahasa minang, e) materi bacaan diterjemahkan berdasarkan i'räb.

Kata Kunci: strategi, kaji duduak, pembelajaran bahasa Arab, maharah al-qirā'ah 


\section{Arabi : Journal of Arabic Studies}

\section{Pendahuluan}

Beberapa ahli dan pemerhati pembelajaran bahasa Arab berpendapat bahwa aspek keterampilan membaca merupakan salah satu yang sulit (Albadi, O'Toole, and Harkins 2017; ElOmari and Bataineh 2018) untuk dicapai para pembelajar bahasa Arab di Indonesia, menurut Mustofa setidaknya ada dua permasalahan utama terkait dengan hal ini yakni aspek internal bahasa Arab dan aspek di luar bahasa Arab (Mustofa, 2017). Aspek internal bahasa yang dimaksudnya ialah terkait dengan pemahaman dan penerapan siswa terhadap gramatika bahasa Arab, sementara aspek non linguistik ialah berkaitan dengan pelaksanaan pembelajaran. Menggunakan gramatika secara aplikatif dalam membaca bahasa Arab tidaklah mudah, mereka yang hapal teori-teori nahwu dan sharaf belum tentu lancar dalam mengaplikasikannya.

Upaya untuk mengatasi kesulitan membaca bahasa Arab telah banyak dilakukan oleh para pemerhati dan pecinta pembelajaran bahasa Arab, seperti ujicoba sebuah metode, media, strategi dan lain-lain. Strategi pembelajaran mahārah qirā'ah telah banyak dikemukakan oleh para ahli pembelajaran dan pemerhati pendidikan bahasa Arab, Siregar pada tahun 2018 misalnya melakukan research tentang strategi pembelajaran keterampilan membaca dengan melihat teori Stephen, hasil penelitiannya menunjukkan bahwa teori Stephen mengarahkan para pelajar untuk berpikir secara kritis terhadap muatan teks (Siregar 2018), sementara Ilmiani mengungkapkan bahwa pembelajaran keterampilan membaca di IAIN Palangkaraya sesuai dengan teori konstruktivisme dapat menggunakan strategi kooperatif, top down atau learning discovery (Ilmiani 2017).

Batmang yang telah melakukan penelitian eksperimen terhadap penggunaan metode kooparatif dalam meningkatkan kemampuan membaca menyimpulkan bahwa pembelajaran dengan metode kooparatif dapat meningkatkan kemampuan membaca di kalangan mahasiswa (Batmang 2016). Erlina yang melakukan ujicoba terhadap SQ4R memperlihatkan hasil pembelajaran membaca bahasa Arab yang menggembirakan (Erlina 2018), sementara Alotaibi dkk yang melakukan desain dan pengembangan mobil-learning untuk pembelajaran bahasa Arab menyimpulkan bahwa model tersebut dapat meningkatkan kemampuan membaca dan menjadikan pembelajaran bahasa Arab bagi non Arab menjadi efektif (Alotaibi, Siraj, and Ismail 2019). Beberapa hasil penelitian ini mengindikasikan urgensi penggunaan strategi dalam pembelajaran keterampilan membaca.

Berkaitan dengan pembelajaran bahasa Arab pada aspek mahārah al-qirō'ah di pondok pesantren pada umumnya menggunakan sumber belajar kitab kuning (Sulaeman 2016), (Rosikh 2018), (Ritonga, Lahmi, and Hakim 2020). Sementara metode yang banyak digunakan ialah sorogan dan bandungan (Fuadah and Sanusi 2017), sepertinya penggunaan metode sorogan dan bandungan menjadi ciri khas utama dan telah melekat dalam sistem pembelajaran yang berlaku di pondok pesantren, menurut Mu'izzuddin dkk kedua metode tersebut sangat efektif dalam meningkatkan keterampilan membaca (Mu'izzuddin, Juhji, and Hasbullah 2019).

Efektifitas metode sorogan dan bandungan sebagaimana diungkapkan Mu'izzuddin dkk tidak sertamerta menjadikan kedua istilah tersebut dikenal pada lingkungan pondok pesantren di wilayah Sumatera Barat seperti di madrasah tarbiyah Islamiyah Batang Kabung, melainkan lembaga ini memiliki strategi tersendiri mereka sebut dengan kaji duduak, penamaan dan penyebutan kaji duduak di lingkungan MTI Batang Kabung menurut buya Idris telah berlaku sejak berdirinya madrasah tersebut dan sudah menjadi istilah yang populer bagi semua ustaz dan santri, dan dalam perjalanannya kaji duduak yang digunakan di MTI Batang Kabung memberikan kontribusi dalam mewujudkan santri yang terampil dalam membaca bahasa Arab, hal ini dibuktikan dengan belum adanya keinginan ustaz untuk beralih ke strategi yang lain, dan santri yang belajar dengan strategi kaji duduak memiliki kemampuan membaca bahasa Arab yang baik.

Namun demikian, keberadaan kaji duduak sebagai strategi pembelajaran belum dikenal oleh masyarakat luas sebagaimana layaknya metode sorogan dan bandungan yang dikenal pada lingkungan pondok pesantren di wilayah Jawa. Terkait dengan itu, penelitian ini bermaksud untuk 
mengungkapkan sistem pembelajaran qirā'ah dengan menggunakan strategi kaji duduak. Fenomena yang ada di pondok pesantren MTI Batang Kabung penting untuk diekspos kepada masyarakat pecinta bahasa Arab dan pembelajarannya, karena penelitian-penelitian terkait dengan pembelajaran mahärah al-qirä'ah objek materialnya lebih menekankan pada metode dan strategi yang sudah dikenal oleh masyarakat pesantren. Selain itu, penelitian yang terkait strategi pembelajaran mahārah al-qirä'ah juga terdapat pada objek material penggunaan teknologi untuk pembelajaran. Adapun hasil penelitian ini dimaksudkan untuk memberikan informasi baru pada pemerhati dan pecinta bahasa Arab dan pembelajarannya dengan harapan dapat diterapkan dalam mengajarkan qirā'ah, hal itu bukan suatu yang mustahil karena hasil analisisnya yang mengungkapkan sistem pembelajaran mulai dari awal sampai akhir kegiatan pembelajaran dengan strategi kaji duduak diungkapkan secara faktual.

\section{Metode}

Penelitian ini dilaksanakan di Madrasah Tarbiyah Islamiyah Batang Kabung yang beralamat di Jl. Adinegoro Batang Kabung, Kecamatan Koto Tangah Kota Padang, pemilihan tempat ini dikarenakan MTI Batang Kabung sebagai salah satu lembaga pendidikan yang bertahan dengan pola lamanya dalam pesatnya arus perkembangan lembaga pendidikan yang berpacu dengan sistem informasi dan teknologi dalam berbagai aspeknya. Adapun waktu yang dibutuhkan dalam penelitian mulai dari tahap perencanaan, pelaksanaan sampai pada analisis dan verifikasi data ialah selama 6 (enam) bulan, yakni sejak September 2019-Februari 2020.

Penelitian ini merupakan bagian dari jenis penelitian kualitatif, sementara pendekatan yang peneliti gunakan ialah ekpos facto, yakni peneliti berusaha untuk mengekspos fakta yang terjadi untuk diketahui oleh masyarakat luas, dengan harapan sistem kaji duduak sebagai strategi pembelajaran qirä'ah dapat digunakan oleh guru di manapun tempatnya, bahan yang digunakan ialah berupa informasi yang terkait dengan sistem kaji duduak sebagai sebuah strategi pembelajaran. Informasi tersebut didapat melalui: a) pengamatan terhadap aktivitas pembelajaran bahasa Arab yang berlangsung di lingkungan MTI Batang Kabung, b) wawancara dengan ustaz dan santri yang terlibat dalam pembelajaran bahasa Arab dengan menggunakan strategi kaji duduak, ustadz dan santri yang diwawancarai ditentukan secara snow ball, c) melakukan analisis terhadap dokumen yang terkait dengan pembelajaran bahasa Arab menggunakan strategi kaji duduak, seperti catatan ustaz, catatan santri, sumber belajar.

Teknik analisis data dilakukan sejak pengumpulan data yang berlangsung secara simultan selama penelitian. Sementara untuk memastikan keabsahan data digunakan triangulasi yang meliputi: a) sumber, dalam mengambil kesimpulan peneliti tidak hanya berhenti pada satu sumber data, tetapi dilakukan verifikasi dengan sumber lain, b) metode, peneliti melakukan kajian terhadap data yang didapat dengan metode tertentu dengan data yang didapat dengan metode lain, c) waktu, data yang didapat pada waktu tertentu dibandingkan dengan data yang didapat pada waktu lain.

\section{Hasil Penelitian dan Pembahasan}

Sistem kaji duduak merupakan salah satu sistem tradisional yang mampu membantu santri untuk membaca beberapa literatur bahasa Arab dengan baik dan tentunya masih relevan diterapkan sampai sekarang terutama di Pondok Pesantren. Sistem ini dipandang sebagai metode yang sangat efektif, karena didasarkan pada basic pengajaran bahasa Arab yang diawali dengan pengenalan gramatika bahasa Arab (nahwu dan sharf) yang merupakan alat untuk memahami literatur bahasa Arab secara jelas dan rinci. Dalam kultur pondok pesantren sendiri sistem kaji duduak ini lebih mengutamakan adanya ikatan emosional yang kuat antara ustadz dan santri. Begitu pula dengan pembelajaran mahārah al-qirā'ah di Pondok Pesantren Tarbiyah Islamiyah Batang Kabung yang menggunakan sistem kaji duduak. Madrasah Tarbiyah Islamiyah Batang Kabung merupakan pondok pesantren tradisional yang masih memakai sistem terjemahan klasik 


\section{Arabi : Journal of Arabic Studies}

berbahasa Minang atau dikenal dengan istilah kaji duduak. Sistem klasik ini merupakan langkah awal yang menjadi pedoman pemahaman terhadap teks-teks berbahasa Arab karya ulama.

Dalam pembelajaran kaji duduak ini santri berhadapan langsung dengan ustadz dan belajar sesuai dengan tingkat kemampuannya. Sesuai dengan hasil pengamatan terlihat bahwa tercipta ikatan emosional dan interaksi yang aktif antara santri dengan ustaz, karena ustadz dapat secara langsung melihat perkembangan dan kemampuan belajar santrinya. Salah satu indikator pembelajaran berkualitas ialah ketika terwujud hubungan emosional serta intraksi aktif antara peserta didik dengan guru (Luz 2015), (Hagenauer, Hascher, and Volet 2015). Oleh karenanya, dari segi proses penggunaan kaji duduak dapat dikatakan efektif karena komunikasi yang terbangun antara pendidik dan peserta didik, akan tetapi, kemampuan berbahasa Arab dengan sistem ini terfokus kepada membaca teks Arab dan terkesan pasif.

Sistem pembelajaran yang digunakan di Pondok Pesantren Tarbiyah Islamiyah Batang Kabung dalam menguasai kitab kuning adalah dengan sistem kaji duduak, dimana para santri duduk berhadapan dengan ustadz, kemudian ustadz membacakan beberapa literatur bahasa Arab (matan) lalu menterjemahkan sesuai dengan kaedah nahwu dan sharf, dilanjutkan beberapa santri diperintahkan untuk mengulangi bacaan sesuai dengan yang dibacakan oleh ustadz setelah itu ustadz memberikan penjelasan (syarah) kepada para santri, sehingga dengan penggunaan sistem kaji duduak ini semakin menambah wawasan serta kemampuan santri dalam membaca literatur bahasa Arab berdasarkan kaedah nahwu dan sharf, kerena adanya sebuah interaksi tanya jawab secara langsung antara guru dan santri serta ditambah adanya pemahaman ilmu qawă'id yang detail. Sistem pembelajaran di Pondok Pesantren Tarbiyah Islamiyah Batang Kabung terfokus pada kemampuan santri dalam pembelajaran kitab gundul yang mengutamakan penguasaan qawā'id.

Dapat diungkapkan bahwa sistem pembelajaran dengan kaji duduak dapat dilihat cirikhasnya dari berbagai aspek, seperti pertama aspek materi pembelajaran, kedua metode, ketiga labelitas dan keempat bentuk evaluasi. Pada aspek materi, pembelajaran mahärah al-qirā'ah dengan strategi kaji duduak ini menggunakan sumber belajar berbahasa Arab yang ditulis oleh para ulama dalam berbagai bidang keilmuan. Misalnya saja pada bidang fiqih digunakan mabādi' al-fiqhiyah, safīnah al-najā, risālah al-jāmi'ah muqaddimah haḍāmiyyah, sullām al-tawfīq, matn al-taqrīb, fatḥ alqarīb, kifāyah al-akhyār, tawdịh al-ahkām. Pada bidang theologi kitab yang biasa digunakan sebagai sumber belajar di pondok pesantren MTI batang Kabung ialah 'aqāid al-diniyyah, 'aqīdah al-awwām, kifāyah al-'awām, fath al-'allām, al-dusūkỉ. Pada bidang hadis sumber rujukan yang digunakan ialah arba'in, 'ulüm al-ḥadits, tanqīh al-qawl al-ḥadits, bulügh al-marām, riyāè alsalihịin. Pada aspek tafsir sumber rujukan yang digunakan ialah tafsir jalālayn, bidang akhlak digunakan nașà'ih al-diniyyah, ta'Tim al-muta'allim, akhläq li al-baninn. Dalam bidang sejarah kitab yang digunakan ialah nür al-yaqin. Sumber belajar yang paling banyak digunakan dalam membaca teks berbahasa Arab ialah terkait dengan ilmu bahasa Arab yang meliputi naḥu dan șaraf seperti matn al-jurūmiyyah, matn al-binā wa al-asās, syarah al-jurümiyyah, syaraḥ al-kaylänì, matn alfiyyah, kawākib al-durriyyah, jāmi' al-durūs al-'arabiyyah, al-'arabiyyah bayna yadayk.

Kesemua sumber belajar tersebut merupakan sumber utama yang digunakan dalam mengajarkan keterampilan mahārah qirā'ah di MTI Batang Kabung. Dalam prakteknya sumbersumber tersebut disesuaikan dengan jenjang santri. Menjadi perhatian dalam penggunaan sumber belajar membaca bahasa Arab ini ialah bahwa semua santri harus menggunakan sumber tersebut tanpa memperhatikan latar belakang dan kemampuan dasar santri, menurut buya Idris pengelompokan hanya dilakukan berdasarkan jenjang santri pada kelas formal. Fenomena ini bertentangan dengan analisis Handayani dkk yang menyatakan bahwa bacaan seharusnya disesuaikan dengan kemampuan dasar peserta didik (Handayani et al. 2018), Machmudah juga menegaskan bahwa materi bacaan seharusnya tidak hanya didasarkan pada jenjang kelas formal melainkan mempertimbangkan homogenitas kemampuan membaca peserta didik dalam jenjang kelas tertentu (Machmudah, Khuzaimah, and Sholihah 2019). 
Sementara hasil wawancara dengan beberapa orang santri menyatakan bahwa sumber belajar membaca bahasa Arab sebagaimana yang digunakan di MTI Batang Kabung tidak menjadi penghalang dalam memahami teks walaupun sebagian mereka tidak memiliki kemampuan yang baik dalam membaca teks tersebut, karena dengan strategi kaji duduak yang diterapkan santri memiliki kesempatan untuk menanyakan materi yang belum mereka pahami kepada ustaz secara langsung. Penerapan strategi kaji duduak menurut santri justru memudahkan mereka memahami dan mengaitkan materi yang mereka pelajari pada bidang tertentu dengan materi yang telah mereka pelajari pada bidang ilmu lainnya. Poin penting dalam hal ini ialah kesimpulan Handayani dkk serta Machmudah dkk tidak selalu dapat diberlakukan pada lembaga pendidikan, melainkan tergantung pada lembaga yang mengajarkan. Berdasarkan observasi terhadap kegiatan pembelajaran kitab kuning di MTI Batang Kabung dapat diungkapkan bahwa sumber belajar qirō'ah yang digunakan berbahasa Arab, dan bagi santri level Tsanawiyah banyak yang memberikan syakal pada kitabnya ketika ustaz membacakan naskah yang harus mereka pelajari.

Adapun metode yang digunakan dalam sistem kaji duduak ialah al-qawā'id wa al-tarjamah, dalam prakteknya ustaz duduk di tengah dan santri duduk menghadap ustaz dengan pola lingkaran atau yang lebih identik dengan halaqah (Abidin et al. 2019), setelah santri dan ustaz duduk sesuai dengan tempatnya masing-masing, kemudian ustaz menyuruh santri untuk membuka kitab yang akan dipelajari sesuai jadwal yang telah ditetapkan sebelumnya. Selanjutnya ustaz membaca materi dengan bacaan yang nyaring (qirä'ah zahriyyah), pada saat ustaz membaca santri dituntut untuk memperhatikan bacaan serta cara membacanya, setelah itu adakalanya ustaz terlebih dahulu meminta santri mengikuti bacaan dan adakalanya ustaz meminta perwakilan santri atau secara bergantian untuk mengulangi bacaan.

Ketika proses tersebut sudah selesai ustaz kemudian menterjemahkan naskah dengan gaya bahasa yang khas, dan terkadang ustaz tidak secara langsung menterjemahkan melainkan meminta dan menanyakan apakah ada di antara santri yang bisa untuk menterjemahkan teks bacaan, jika ada maka ustaz mempersilahkan kepada santri untuk menterjemahkannya, dan jika tidak ada di antara santri yang bisa atau berani maka ustaz secara langsung akan menterjemahkannya. Pada saat ustaz menterjemahkan teks santri memperhatikan cara menterjemah dan menuliskan arti kosakata yang sulit di pinggir kitab dengan tulisan arab melayu, kegiatan ini oleh kalangan MTI disebut dengan istilah mendhabit.

Berdasarkan hasil wawancara dengan santri diketahui bahwa langkah seperti yang dijelaskan di atas berlangsung setiap mereka mempelajari kitab kuning, pernyataan santri ini juga diperkuat dengan hasil wawancara dengan buya Irwanto yang menegaskan bahwa untuk mengajarkan kemampuan membaca bahasa Arab terutama kitab kuning langkah yang ditempuh adalah: 1) ustaz membaca secara nyaring, 2) santri diminta untuk mengulang bacaan, atau perwakilan santri ada yang membaca, 3) terjemah, (adakalanya santri dan terkadang ustaz secara llangsung), 4) santri diminta untuk membaca secara diam, 5) mengi'rāb. Penggunaan kaji duduak sebagaimana dijelaskan di atas tampaknya tidak terlihat perbedaan mendasar dengan tharíqah al-Qawä'id wa alTarjamah (Aqel 2013), (Akar 2013). Hanya saja dalam sistem kaji duduak penerjemahan didasarkan pada posisi I'rāb sebuah kata dan tidak menggunakan standar bahasa sasaran.

Setelah proses menterjemah sudah selesai ustaz mulai menjelaskan gramatika yang terdapat pada teks baik dari segi naḥwunya maupun șarafnya. Pembahasan terhadap gramatika yang disebut dengan mengi'rāb diurai secara rinci bentuk kata dari segi șarafnya, bentuk kata ditinjau dari segi jumlahnya, apa i'rābnya, kenapa itu i'rābnya dan seterusnya. Hal yang menarik perhatian dalam tahapan ini ialah bahwa kalangan ustaz dan santri di MTI Batang Kabung memiliki kode, label dan istilah sendiri yang kemudian nanti mempengaruhi makna kata yang diebabkan oleh i'rāb. Dalam hal ini pola pikir yang sudah tertanam di kalangan santri ialah bahwa arti kata disesuaikan dengan i'rābnya, mereka tidak bisa menerima sistem penerjemahan yang menggunakan bahasa Indonesia yang sesuai dengan EYD. 


\section{Arabi : Journal of Arabic Studies}

Adapun bentuk labelitas yang sudah baku di kalangan santri dan ustaz pada MTI Batang Kabung ialah terlihat pada tabel 1 di bawah ini:

Tabel 1 labelitas i'rāb dan pemaknaannya

\begin{tabular}{|c|c|c|c|}
\hline No & Rumus I'rāb & $\begin{array}{l}\text { Kode Penyebutan (bahasa } \\
\text { minang) }\end{array}$ & Contoh \\
\hline 1 & $\begin{array}{l}\text { Mubtadā (^) dan } \\
\operatorname{khabar}(\dot{\nearrow})\end{array}$ & $\begin{array}{l}\text { Baramulo (Mubtada) dan Baa } \\
\text { lah baramulo (khabar) }\end{array}$ & زيد قائم \\
\hline 2 & Fa'il ف & Oleh & قال أحمد \\
\hline 3 & نف Nāib al-Fā'il & Akan dio & خلق الإنسان ضعيفا \\
\hline 4 & مف Maf'ūl bih & Akan & ضرب زيد عمرا \\
\hline 5 & مع Maf'ūl ma'ah & Basarato & جاء الأمير والجيس \\
\hline 6 & مل Maf'ūl li ajlih & Karano & جئت رغبة فيك \\
\hline 7 & مط Maf'ūl muṭlaq & Akan Samparono & نصر خالد عمرا نصرا \\
\hline 8 & ظز Dzharaf zaman & Pado & ولد النبي يوم الإثنين \\
\hline 9 & ظم Dzharaf makan & Di/Pado & يلعب زيد أمام المسججد \\
\hline 10 & ن ن Na'at & Nan & حضر أحمد الشجاع \\
\hline 11 & Bayān با & Nyatolah & من السـماء من ماء \\
\hline 12 & بد Badal & Sia nan iyo & جاء زيد أخوك \\
\hline 13 & حا Hāal & Hal keadaan & جاء أحمد راكبا \\
\hline 14 & جawab syarat in & Baa lah jikok & إن قام أحمد قام بكر \\
\hline
\end{tabular}

Data pada tabel di atas dapat dijelaskan bahwa pertama i'rāb mubtadā diberi rumus mim dan khabar diberi rumus kha mubtada diberi kode penyebutan dengan istilah baramulo dan khabar diberi kode penyebutannya dengan baa lah baramulo. sebagai contoh: زيد فيائم diterjemahkan dengan bahasa minang Baramulo si Zaid Baa lah baramulo berdiri dengan mengetahui kode penyebutan ini, setiap santri yang mendengarkan terjemahan dari ustadz dengan kode penyebutan baramulo maka dapat dipastikan bahwa kalimat itu mubtadā dan ketika mendengarkan kode penyebutan ba a lah baramulo maka dapat dipastikan itu adalah khabar dari mubtadā.

قال أحمد Selanjutnya untuk fá'il diberi rumus fa kode penyebutannya adalah oleh contohnya terjemahannya telah berkata oleh si ahmad ada perbedaan kode penyebutan antara fa'il yang zahir dengan fáil yang mustatir (tersembunyi) ketika ditemukan fá'il yang tersembunyi maka kode penyebutannya adalah hionyo, misalnya قال إني أعلم ما لا تعلمون terjemahannya adalah telah bakato hionyo Allah bahwa sesungguahnyo aku baa lah sesungguahnyo mengetahui aku akan barang yang tidak mengetahui kamu. Ketika para santri mendengarkan kode penyebut tersebut maka dapat dipastikan bahwa lafaz tersebut posisinya fá'il. Adapun nāib al-fá̀il oleh kalangan MTI diberi rumus nun dan fa kode penyebutannya adalah akan dio contohnya خلق الإنسان ضعيفا terjemahannya telah diciptakan akan dio insan akan basifaik lamah, pada saat santri mendengar kode penyebutan di atas maka mereka akan memahaminya bahwa posisi i'rāb kalimat tersebut sebagai nāib al-fá'il.

Sementara i'räb maf'ül bih diberi rumus mim dan fa, adapun kode penyebutannya akan contohnya ضرب زيد عمر terjemahannya telah memukul oleh si zaid akan si umar ketika santri mendengar kode penyebutan di atas maka dapat dipastikan bahwa lafaz tersebut adalah maf'ül bih. Pengkodean dan penerjemahan lain ialah terhadap maf' $\bar{u} l$ ma'ah diberi rumus mim dan 'ain kode penyebutannya adalah basarato contohnya جاء الأمير والجيس terjemahannya telah datang oleh amir basarato tentara ketika santri melihat huruf waw diberi kode dengan kode penyebutan di atas maka dapat dipastikan bahwa lafaz tersebut adalah maf'ūl ma'ah. Adapun untuk maf'ūl li ajlih oleh 
جئت رغبة kalangan MTI diberi rumus mim dan lam kode penyebutannya adalah karano contohnya فيك terjemahannya telah datang aku karano harok pado engkau ketika santri mendengar kode penyebutan di atas maka dengan sendirinya mereka memiliki pemahaman bahwa i'rāb kata tersebut ialah maf'ül li ajlih.

Adapun untuk maf'ūl mutlaq diberi rumus nun dan ta oleh kalangan MTI Batang Kabung, sementara penerjemahannya dengan bahasa minang ialah akan samparono, misalnya نصر خالد عمرا

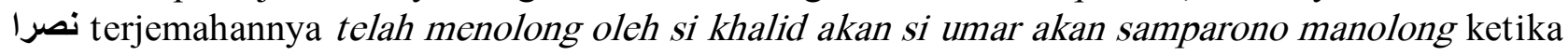
santri mendengar kode penyebutan di atas maka dapat dipastikan bahwa lafaz tersebut adalah maf'ül mutlaq. Sementara untuk zaraf zaman diberi rumus za dan zai kode penyebutannya adalah pado contohnya terjemahannya dilahirkan akan dio nabi pado hari senen, apabila santri mendengarkan cara penerjemahan yang seperti ini maka mereka akan memahami i'rāa kata tersebut sebagai zaraf zaman. Sementara untuk zaraf makan ustaz memberikan rumus za dan mim kode penyebutannya adalah di/pado contohnya يلعب زيد أمام المسجد terjemahannya sedang bermain oleh si zaid di/pado muko masjid, ketika santri mendengar kode penyebutan di atas maka dapat dipastikan bahwa lafaz tersebut adalah zaraf makan.

Selain pemberian kode dan label terhadap beberapa i'räb yang disebutkan di atas, ustaz dan santri di MTI batang Kabung juga memiliki pemahaman yang sama terhadap kode, label dan penerjemahan na'at, mereka memberikan rumus nun dan kode penyebutan serta pemaknaannya nan terhadap na'at, misalnya حضر أحمد الثجاع terjemahannya telah hadir oleh si ahmad nan barani, ketika santri mendengar kode penyebutan dan penerjemahan di atas maka dapat dipastikan bahwa lafaz tersebut adalah na'at.

Adapun untuk bayān kalangan MTI Batang Kabung memberikan rumus ba dan alif, dan kode penyebutannya adalah nyatolah, contohnya من السماء من ماء terjemahannya dari langik nyatolah dari pado aia ketika santri mendengar kode penyebutan di atas maka pemahaman yang ada dalam pikiran mereka adalah bahwa i'rāb kalimat tersebut adalah bayān. Selain itu, labelitas terhadap i'rāb badal, terkait masalah ini ustaz memberikan rumusnya ba dan dal, sementara penerjemahannya ialah sia nan iyo, misalnya جاء زيد أخوك terjemahannya telah datang oleh si zaid sia nan iyo saudaro engkau, ketika santri mendengar penerjemahan yang sedemikian rupa mereka akan memahaminya bahwa $i$ 'rāb kata tersebut ialah badal.

Untuk i'rāb ḥâl, di pesantren MTI Batang Kabung diberikan rumus dengan ha dan alif, sementara kode penyebutannya adalah hal keadaan, misalnya جاء أحمد راكبا terjemahannya telah datang oleh ahmad hal keadaan baracak, jika santri mendengar cara penerjemahan seperti ini maka mereka akan dapat memahami bahwa i'rāb kata tersebut adalah hạal. Sementara untuk i'rāb jawāb syarat in, ustaz di MTI Batang Kabung memberikan rumus jim, dan penerjemahannya adalah ba a lah jikok, misalnya إن قام أحمد قام بكر terjemahannya jikok telah berdiri oleh ahmad baa lah jikok telah berdiri oleh bakar, pada saat ustaz menerjemahkan sebuah kalimat dengan penerjemahan seperti ini maka santri akan memahami bahwa i'rāb kata tersebut adalah jawāb syarat.

Beberapa label dan kode serta penerjemahan i'rāb sebagaimana yang dijelaskan di atas telah melekat dalam proses pembelajaran mahärah al-qirā'ah di pesantren MTI Batang Kabung. Keberadaan istilah dan label serta kode penerjemahan sebagaimana dijelaskan di atas memberikan kemudahan bagi santri dalam memahami serta mengaktualisasikan kode dan istilah tersebut dalam membaca dan menterjemahkan kitab kuning. Pernyataan ini didasarkan pada hasil wawancara dengan sejumlah santri yang menyatakan bahwa pengkodean dan istilah yang disampaikan oleh ustaz memberikan kemudahan dalam memahami posisi i'rāb serta jabatan kata dalam hal gramatika bahasa Arab, ketika posisi dan jabatan kata telah diketahui maka artinya juga akan dapat diketahui.

Pembelajaran mahārah al-qirā'ah dengan sistem kaji duduak juga dapat dilihat cirikhasnya dari aspek evaluasi. Dalam aspek ini, evaluasi keterampilan membaca yang digunakan dalam sistem kaji duduak ialah evaluasi langsung. Maksudnya adalah ustaz secara langsung memberikan penilaian kepada semua santri yang ikut dalam proses pembelajaran tanpa harus menunggu jadwal 


\section{Arabi : Journal of Arabic Studies}

evaluasi yang ditetapkan oleh pihak pesantren. Realita model evaluasi yang dilakukan dalam pembelajaran mahärah al-qiräăh di MTI Batang Kabung memiliki perbedaan dengan temuan Dhiauddin yang melakukan penelitian pembelajaran qirä'ah pada pondok pesantren di Aceh, dimana dalam kesimpulannya bahwa guru melakukan evaluasi membaca melalui tes suara (Dhiauddin 2018). Perbedaan itu semakin jelas ketika dilihat operasional evaluasi yang berlaku di MTI Batang Kabung, ketika tahapan ustaz sudah selesai membacakan naskah bahasa Arab, masing-masing santri secara bergiliran disuruh untuk membaca kembali materi yang telah dibaca oleh ustaz.

Berdasarkan hasil pengamatan terhadap fenomena di lapangan diketahui bahwa kesalahan membaca yang dapat dianulir ialah maksimal tiga kali untuk satu tema, jika kesalahan membaca lebih dari tiga maka santri tersebut tanpa diperintahkan oleh ustaz akan melaksanakan sanksi berupa qiyām (berdiri) di depan santri lain, hasil pengamatan ini juga sesuai dengan pernyataan Buya Idris yang menjelaskan bahwa dalam kaji duduak santri tidak selalu duduk, bagi santri yang tidak mampu untuk membaca secara benar dia justru harus tagak (berdiri). Kesadaran santri menjalankan sanksi ini menjadi fenomena yang sudah melekat dalam pembelajaran qiräah dengan sistem kaji duduak di pesantren MTI Batang Kabung. Begitu juga dalam hal menterjemahkan teks bacaan, ketika kesalahan sudah lebih dari tiga kali maka dengan sendirinya santri yang membaca secara salah tersebut akan melaksanakan sanksi tanpa diperintahkan oleh ustaz. Kesalahan itu diketahui dari peringatan yang diberikan ustaz dalam bentuk hitungan wāhid, itsnayn, intahā.

Evaluasi dalam menterjemah naskah dalam sistem kaji duduak tidak menggunakan standar bahasa yang sesuai dengan ejaan yang disempuranakan atau standar bahasa Indonesia yang baik dan benar melainkan terjemah yang sesuai dengan label dan kode yang telah dikenal oleh kalangan pondok pesantren, pernyataan ini dipertegas oleh buya Mulyadi yang mengatakan bahwa ketika naskah diterjemahkan tanpa mengikutsertakan terjemahan i'rāb atau jabatan kata dalam sebuah kalimat maka terjemahan itu dianggap salah. Pola penterjemahan dengan mengutamakan gramatika bahasa sumber tentu akan sulit dipahami oleh pengguna bahasa target (Nurbayan 2014), yang menjadi pertimbangan seorang mutarjim seharusnya adalah gramatika bahasa target bukan bahasa sumber (Akmaliyah 2016). Enani juga menegaskan bahwa terjemahan yang benar ialah terjemahan yang mengutamakan maksud yang dituangkan sesuai dengan kaeah bahasa target bukan bahasa sumber (Enani 2000). Yousuf juga menegaskan bahwa terjemahan yang berkualitas itu dapat ditunjukkan dengan mengutarakan pokok pikiran yang terdapat dalam bahasa asli (Yousuf 2006), Astari dkk juga menjelaskan bahwa standar utama dalam penerjemahan ialah kesesuaian aturan hasil terjemahan dengan bahasa sasaran (Astari et al. 2020).

Beberapa pendapat di atas menunjukkan bahwa strategi menterjemah yang digunakan dalam sistem kaji duduak perlu untuk diperbaharui atau dialihkan kepada sistem terjemah yang mengutamakan maksud teks dan diutarakan dengan bahasa yang sederhana serta mudah dipahami oleh orang yang mendengarkan atau membaca hasil terjemahan tersebut. Karena jika pola penterjemahan seperti yang ada dalam sistem kaji duduak ini tetap dipertahankan maka kesulitan memahami maksud yang akan muncul, kesulitan menangkap makna itu tidak hanya pada orang yang mendengarkan atau membaca hasil terjemahan tetapi kalangan santri yang ikut dalam dalam penterjemahan seperti itu juga banyak yang tidak memahami maksud teks walaupun sudah diterjemahkan dengan pola terjemahan sistem kaji duduak.

\section{Simpulan}

Temuan dan uraian serta hasil pembahasan di atas menunjukkan sistem kaji duduak sebagai strategi pembelajaran mahārah al-qirāăh sebagaimana yang terdapat di pondok pesantren madrasah tarbiyah Islamiyyah Batang Kabung terlihat dari: pertama, materi atau sumber belajar yang digunakan ialah semuanya berbahasa Arab yang meliputi berbagai kajian tentang ilmu-ilmu keislaman, kedua, metode yang digunakan lebih identik dengan tharíqah al-qawā'id wa altarjamah, namun sistem kaji duduak pada aspek terjemah menekankan pentingnya posisi kata 
dalam sebuah kalimat, sehingga hasil terjemahan harus memperlihatkan apa i'rāb sebuah kata. ketiga, adanya labelitas dan kode serta terjemahan yang khas dengan kalangan pondok pesantren MTI Batang Kabung, label dan kode terhadap i'rāb yang digunakan di MTI Batang Kabung menunjukkan kekhasan sistem kaji duduak dalam pembelajaran mahārah al-qirāăah, keempat, model evaluasi yang diterapkan ialah berupa evaluasi langsung, ustaz secara langsung dalam proses pembelajaran melaksanakan evaluasi terhadap kemampuan santri dalam membaca teks dan menterjemahkannya sesuai dengan pola penterjemahan yang berlaku di MTI Batang Kabung.

Penelitian ini telah berhasil mengungkapkan sistem kaji duduak sebagai strategi pembelajaran mahärah al-qirä'ah yang memiliki nilai dalam pembelajaran bahasa Arab terutama pada aspek keterampilan membaca, namun pada berbagai aspek masih banyak yang belum terungkap secara mendalam baik pada aspek keterampilan santri dalam membaca, kompetensi gurunya, kelayakan sistem kaji duduak sebagai strategi dalam pembelajaran qirā'ah di era digital dan lain sebagainya, dan tentunya aspek-aspek yang belum terungkap dapat dijadikan sebagai garapan penelitian untuk setiap pemerhati bidang pembelajaran bahasa Arab.[]

\section{References}

Abidin, Mohd Zahirwan Halim Bin Zainal., Nor Aileen Binti Ibrahim, Huzaimah Binti Ismail, Muhammad Yusri Bin YusofSalleh, Paiz Hassan, and Abd. Munir Mohd Noh. 2019. "The Implementation of Halaqah Method at Madrasah Muhammadiah, Pondok Sungai Durian, Kuala Krai, Kelantan”, International Journal of Academic Research in Business and Social Sciences, Vol. 9, No. 10.

Akar, Sylvia. 2013. "Teaching Arabic As Foreign Lannguage: From Grammar-Translation Method to The Audio-Lingual Approach”, Studia Orientalia Electronica, Vol. 114.

Akmaliyah. 2016. "Model dan Teknik Penerjemahan Kalimat Bahasa Arab ke dalam Bahasa Indonesia", Al-Tsaqafa: Jurnal Ilmiah Peradaban Islam, Vol. 16, No. 1.

Albadi, Nouf Mohammed, John Mitchell O'Toole, and Jean Harkins. 2017. "Reading Difficulty and Language Features in an Arabic Physics Text", Electronic Journal of Science Education, Vol. 12, No. 8.

Alotaibi, Faihan Dulaym., Saeedah Siraj, and Wail Muil Alhaj Said Ismail. 2019. "Design and Development Of Mobile-Learning Model For Teaching Arabic Language Reading Skills To Non-Arab Speakers In Higher Education Institutions", Opcion, Vol. 35, No. 19.

Aqel, Ishraq M. 2013. "The Effect of Using Grammar-Translation Method on Acquiring English as a Foreign Language”, International Journal of Asian Social Science, Vol. 3, No. 12.

Astari, Rika., Yosroh, Abdul Malik, Ahmad Arifin bin Sapar, and Nurina Dyah Putrisari. 2020. "Padanan Kosakata Arab Dalam Al-Qur'an Terjemah Versi Indonesia dan Malaysia", Arabi: Journal of Arabic Studies, Vol. 5, No. 1.

Batmang. 2016. "Tathbīq Al-Ta'allum al-Ta'āwunì fî̀ Tanmiyah Mahārah al-Qirā'ah", AnNabighah, Vol. 18, No. 1.

Dhiauddin. 2018. “Ta’īm Mahārah al-Qirāah fĩ al-Zāwiyah al-Islāmiyyah al-Salafiyah Bi Aceh”, Arabi : Journal of Arabic Studies, Vol. 2, No. 1.

Enani, Mohamed. 2000. Fann Al-Tarjamah. Kairo: al-Shirkah al-Miṣriyyah al-'Ālimiyyah linnashar.

Erlina, Nova. 2018. "IJLECR The Increase of Student' Arabic Reading Skills Through the Application of SQ4R Learning Technique", International Journal of Language Education and Culture Review, Vol. 4, No. 1. 


\section{Arabi : Journal of Arabic Studies}

Fuadah, Fitriyah Samrotul., and Hary Priatna Sanusi. 2017. "Manajemen Pembelajaran Di Pondok Pesantren”, IsEma: Jurnal Islamic Education Manajemen, Vol. 2, No. 2.

Hagenauer, Gerda., Tina Hascher, and Simone E Volet. 2015. "Teacher Emotions in the Classroom: Associations With Students' Engagement, Classroom Discipline and the Interpersonal Teacher-Student Relationship”, Eur J Psychol Educ, Vol. 30.

Handayani, Wahyuni., Wawan Setiawan, Parlindungan Sinaga, and Andi Suhandi. 2018. "Physics Student Teachers' Reading Comprehension Skills of Science and Physics Texts", Jurnal Inovasi Pendidikan IPA, Vol. 4, No. 2.

Ilmiani, Aulia Mustika. 2017. “Ta'Tim Mahārah al-Qirā'ah Fi Dhaw’i al-Naẓariyyah al-Bināiyyah al-Ijtimā'iyyah Vigotsky Dirāsah al-Hālah fì Jāmi'ah Palangkaraya al-Islāmiyyah alHukūmiyyah”, Al-Ta'rib: Jurnal Pendidikan Bahasa Arab Dan Kebahasaan, Vol. 5, No. 2.

Luz, Fredson Soares dos Reis da. 2015. "The Relationship Between Teachers and Students in the Classroom: Communicative Language Teaching Approach and Cooperative Learning Strategy to Improve Learning", Thesis, Bridgewater State University.

Machmudah, Umi, Khuzaimah Khuzaimah., and Mufidatus Sholihah. 2019. "The Characteristics of Arabic Language Textbooks of Madrasah Ibtidaiyah", Jurnal Al Bayan: Jurnal Jurusan Pendidikan Bahasa Arab, Vol. 11, No. 1.

Mu'izzuddin, Mochammad., Juhji, and Hasbullah. 2019. "Implementasi Metode Sorogan dan Bandungan Dalam Meningkatkan Kemampuan Membaca Kitab Kuning”, Geneologi PAI: Jurnal Pendidikan Agama Islam, Vol. 6, No. 1.

Mustofa, Nurul Hana. 2017. "Musykilāt Ta' lim Mahārah al-Qirā'ah Wa 'Ilājuhā bi al-Madrasah alThānawiyyah al-Islāmiyyah al-Ma'ārif Singosari Malang”, Abjadia: International Journal of Education, Vol. 2, No. 1.

Nurbayan, Yayan. 2014. "Pengaruh Struktur Bahasa Arab Terhadap Bahasa Indonesia dalam Terjemahan Al-Qur'an”, Arabiyat: Jurnal Pendidikan Bahasa Arab Dan Kebahasaaraban, Vol. 1, No. 1.

el-Omari, Abdallah Hussein., and Hussein Mohammad Bataineh. 2018. "Problems of Learning Arabic by Non-Arabic Speaking Children: Diagnosis and Treatment”, Journal of Language Teaching and Research, Vol. 9, No. 5.

Ritonga, Mahyudin., Ahmad Lahmi, and Rosniati Hakim. 2020. "The Existence of Yellow Books (Kitab Kuning) as the Sources of Islamic Studies at Islamic Boarding Schools within the Industrial Revolution Dialectics", International Journal of Psychosocial Rehabilitation, Vol. 24, No. 8.

Rosikh, Fahrur. 2018. “Arah Baru Pendidikan Bahasa Arab di Pondok Pesantren Sunan Drajat Paciran Lamongan”, Jurnal At-Ta'dib, Vol. 13, No. 2.

Siregar, Zulli Umri. 2018. "Istirātijiyyah Mahārah al-Qirā'ah fi Naẓriyah STIFIn", Jurnal Izdihar: Journal of Arabic Language Teaching, Linguistics, and Literature, Vol. 1, No. 1.

Sulaeman, Eman. 2016. "Model Pembelajaran Qiraah Al-Kutub untuk Peningkatan Keterampilan Membaca Kitab Tafsir”, Al-Bayan: Jurnal Studi Ilmu Al-Qur'an Dan Tafsir, Vol. 1, No. 2.

Yousuf, Mohamed Hasan. 2006. Kayfa Tutarjim. Kairo: Dār al-Kutub al-’Ilmiyyah. 